\title{
Somatic cell count in quarter foremilk of cows from small herds with a high level of subclinical mastitis
}

\section{Maria Fandrejewska}

The Agricultural University of Warsaw

Department of Home Economics

Noiroursinowska 166, 02-766 Warszava. Poland

(Received 3 December 1992; accepted 23 February 1993)

\section{ABSTRACT}

Aseptic foremilk samples of 213 cows from 77 small farms were collected. Of 852 samples, $65.5 \%$ were infected. The most frequently isolated pathogens were Streptococcus agalactiae $(22.7 \%)$, Staphylococcus aureus (18.8\%) and Staphylococcus epidermidis $(18.3 \%)$. Somatic cell count (SCC. in thousand $/ \mathrm{ml})$ in foremilk samples, determined by Fossomatic, ranged significantly $(\mathrm{P}<0.01)$ between bacteria from $313^{\circ}$ (non-infected) to $2128^{\circ}$ cells $/ \mathrm{ml}$ (infected by Streptococcus species). A high percentage of infected samples with no or weak SCC reaction was observed within all bacteriological findings. Thresholds of $120^{\circ}$ cells, determined from a density distribution of SCC in uninfected an infected quarters, correctly detected $68 \%$ samples with 33 and $31 \%$ false negatives and false positives, respectively. Corresponding proportions at a threshold of $410^{\prime}$ cells, estimated from healthy quarters were 55,66 and $14 \%$. The correlation coefficient between the SCC and the California Mastitis Test (CMT) was 0.61 . For both SCC and CMT test the probability of misclassification for quarters infected with secondary pathogens was higher than those infected by streptococci.

KEY WORDS: mastitis, udder pathogens, SCC. CMT, threshold

\section{INTRODUCTION}

The subclinical form of mastitis shows no visible signs of intramammary infection, but the number of epithetical cells and leukocytes (called the somatic cell count - SCC) will be elevated.

The best method of diagnosing mastitis is bacteriological analysis of quarter foremilk in combination with SCC (IDF, 1987). In mass examinations, diagnosis has been limited to measuring bulk SCC levels alone (Gordon et al., 1980). Correct classification of milk samples into infected and uninfected groups depends on an SCC threshold; $500^{\circ}$ cells $/ \mathrm{ml}$ is commonly accepted as the 
threshold value. A more recent proposal of the International Dairy Federation (1987) is lower (250' cells), especially when individual quarter samples are used for diagnosis.

The single most important factor affecting SCC in milk is the infection status of the mammary gland (Brolund, 1985). The SCC level of bacteriological findings differs between species of bacteria (Hogan et al., 1988). However, information on the relationship between SCC and the bacterial species present is sparse and unreliable (IDF, 1987; Timms and Schultz, 1984; Vecht and Wisselink, 1990).

Contrary to other countries, milk production in Poland is based on a large number of small herds with relatively poor hygienic conditions. High mastitis prevalence in such herds has been reported by several authors (e.g. Kozanecki and Kostrzyński, 1987; Kurek et. al., 1990), but there is little information concerning the degree of inflammatory response to the type of infection (Kostrzyński and Kozanecki, 1990). Moreover, while automatic counters (such as Fossomatic) are predominant for monitoring of SCC in most countries the indirect methods, like the California Mastitis Test (CMT), have until now been used alone. So far, no attempt has been made to investigate the validity of the SCC threshold with reference to small dairy herds.

The objectives of this study were 1. to examine the influence of udder pathogens on SCC and CMT score; and 2. to investigate the predictive value of SCC thresholds in detecting mastitis in small herds with high rates of bacterial infection.

\section{MATERIAL AND METHODS}

Milk which originated from 77 small farms (each from 2 to 7 cows) samples were obtained from cows with no clinical sings of mastitis. On these farms animals were kept in conditions typical for the central region of Poland. Cows were normally milked by hand and the milk yield was on the average of ca 30001 per year. Most animals were in their 5-6 lactation and cows with colostral milk (7 days post partum) and those in late lactation (21 days pre partum) were excluded from the study.

A foremilk sample from each quarter was collected from all cows at the morning milking. Prior to collection the udder was washed thoroughly with water and dried with a towel. Teats were carefully cleaned with $70 \%$ ethanol. The first 4 milk streams were rejected, but the next ones were examined macroscopically for abnormalities. The CMT-test was carried out with a commercial regent ,Mastirapid" by mixing $2.5 \mathrm{cc}$ of milk with $2.5 \mathrm{cc}$ of reagent according to the Polish standard methodology (Wiśniowski, 1965). The reactions were graded into five categories: negative 1 ("-"), trace 2 ("-+"), positive 3 ("+"), positive 
$4("++")$ and positive $5("+++")$. Milk samples were obtained aseptically from each quarter and put into sterile vials: one for bacterial culture evaluation and the second for somatic cell count determination. The samples were delivered to the laboratory within two hours and immediately analyzed. The bacteriological examination of milk was done with methods obligatory in Poland (Instruction, 1978). The samples were determined as infected if pathogens were present. Pathogens were classified as follows: major pathogens comprised of Staphylococcus aureus, Streptococcus agalactiae, Streptococcus species (other than Streptococcus agalactiae) and minor pathogens comprised of Streptococcus epidermidis and micrococci.

For all samples the somatic cell count was determined by the Fossomatic apparatus (Foss-Electric, Hillerod, Denmark). The SCC were denoted in 1000 cells per $1 \mathrm{ml}$ and transformed to a log scale with base 10 (LSCC) to allow statistical analysis because cell counts formed non-normal distributions with a pronounced skewness to the right. Where appropriate, the geometric mean (GSCC) was calculated from the LSCC.

In order to exclude systematic effects such as herd, parity and stage of lactation, data for each quarter were computed as the difference from the SCC of milk from the apparently healthiest quarter of the same cow (Mijnen et al.. 1982). The healthiest quarter was the one which was pathogen-free and had the lowest SCC. Consequently the cell count difference of a certain quarter was computed as the actual cell count of that quarter minus the cell count of the quarter showing the lowest cell count. A total 363 comparisons were done.

In order to determine the threshold value of somatic cells, quarters originating from the same udder were divided into groups of healthy and mastitic, respectively. Based on means and standard deviations, the intersection points of the density distribution of somatic cells in healthy and mastitic quarters were determined. Infected quarters with cell counts below the estimated or proposed cell count threshold were termed false negatives $(F N)$ while noninfected quarters with cell counts above that threshold were termed false positives (FP) (Andrews et al., 1983). A total 852 foremilk samples were collected from 213 udders.

\section{RESULTS AND DISCUSSION}

The low rate of contaminated samples (below $2 \%$ ) indicates proper sampling procedures and that most of the bacteria isolated were recovered from the gland or the teat canal.

The overall distributions of bacteriological quarter status are shown in Table 1 . Totally $34.5 \%$ of samples were classified as negative. Different species of pathogens causing udder infection were detected. Of 852 quarter foremilk 
TABLE 1

Infection status of 852 quarters

\begin{tabular}{|c|c|c|c|c|}
\hline \multirow{2}{*}{\multicolumn{2}{|c|}{ Pathogen isolated ${ }^{x)}$}} & \multirow{2}{*}{ No. } & \multicolumn{2}{|c|}{ Percent of } \\
\hline & & & total & infected \\
\hline \multirow[t]{2}{*}{ None } & & 294 & 34.5 & - \\
\hline & Streptococcus agalactiae & 127 & 15.0 & 22.7 \\
\hline \multirow[t]{2}{*}{ Major } & Other strcptococci & 54 & 6.3 & 9.7 \\
\hline & Staphylococcus aureus & 105 & 12.3 & 18.8 \\
\hline \multirow[t]{2}{*}{ Minor } & Staphylococcus epidermidis & 102 & 12.0 & 18.3 \\
\hline & Micrococcus sp. & 53 & 6.2 & 9.5 \\
\hline \multicolumn{2}{|l|}{ Mixed } & 64 & 7.5 & 11.5 \\
\hline \multicolumn{2}{|c|}{ Other } & 53 & 6.2 & 9.5 \\
\hline \multicolumn{2}{|c|}{ Total infected } & 558 & 65.5 & 100.0 \\
\hline
\end{tabular}

${ }^{x)}$ Pathogens were isolated from a simple sample

samples $33.6 \%$ were positive for major pathogens and $18.2 \%$ were positive for minor pathogens. Streptococcus agalactiae was isolated in $22.7 \%$ and appeared to be the primary organism causing udder infection of the cows. The next most frequently isolated major pathogen was Staphylococcus aureus (18.8\%). Staphylococcus epidermidis was the predominant minor pathogen $(18.3 \%)$. Other mixed organisms as well as miscellaneous pathogens (if bacteriological status could not be confirmed, due to the presence of mixed cultures and organisms

TABLE 2

Arithmetic (A) and geometric (G) means of somatic cell count (x 1000/ml) in foremilk by bacteriological status of quarter $(n=735)$

\begin{tabular}{lrc}
\hline \multirow{2}{*}{ Pathogen } & \multicolumn{2}{c}{ Mean of SCC } \\
\cline { 2 - 3 } None & A & G \pm s.d.(log) \\
Staphylococcus aureus & 313 & $61 \pm 0.728$ A \\
Streptococcus agalactiae & 683 & $168 \pm 0.749$ B \\
Streptococcus sp. & 1129 & $349 \pm 0.682$ C \\
Staphylococcus epidermidis & 2182 & $512 \pm 0.825$ C \\
Micrococcus sp. & 347 & $156 \pm 0.559$ B \\
\hline Major & 1023 & $118 \pm 0.793$ AB \\
Minor & 1164 & $287 \pm 0.756$ \\
\hline Total infected & 579 & $142 \pm 0.672$ \\
\hline Overall mean & 958 & $224 \pm 0.741$ \\
\hline
\end{tabular}

A, B, C, D - Means with different superscripts are significantly different $P<0.01$ 


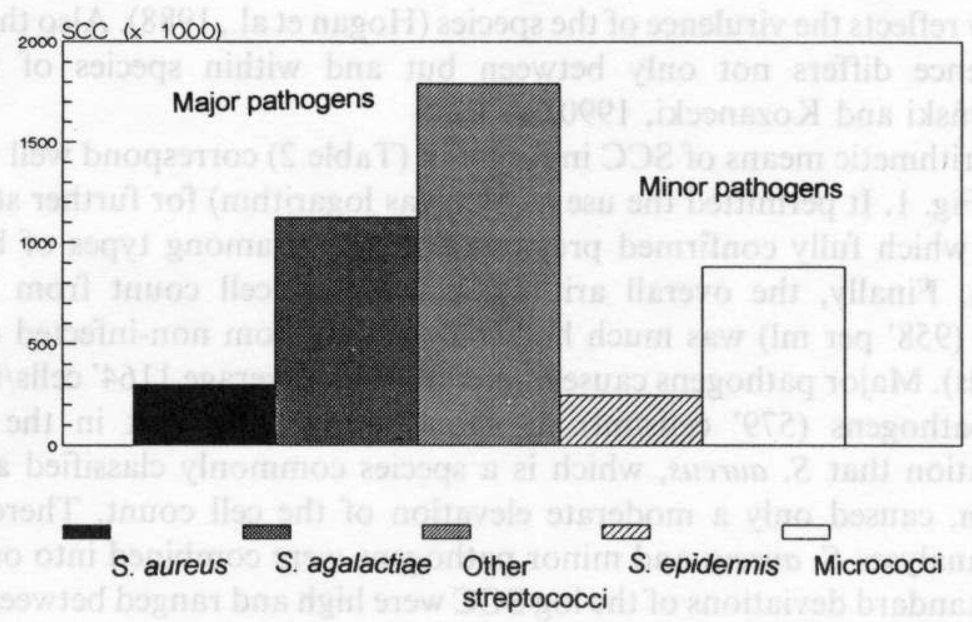

Fig. 1. Effect of various pathogens on cell count as difference with the healthiest quarter within udders.

causing sporadic infections) which consist at least $21 \%$ of total infected samples are shown in Table 1. The other Polish field studies (Malinowski et al., 1992; Kostrzyński and Kozanecki, 1990) also reported that $S$. agalactiae and $S$. epidermidis are the most common bacteria in milk.

Pathogens were isolated in all herds; prevalence ranged from 12 to $100 \%$. In general, there were only 13 cows $(6 \%)$ without bacteria. On the other hand, sixty three udders $(30 \%)$ had pathogens in all of their quarters.

The level of overall bacterial infection presented here $(65.5 \%)$ was hight but it was typical for home milk production. For example, Malinowski et al. (1992) found the presence of bacteria $(46.4 \%)$ in quarters when samples with only positive CMT reaction were examined. A very low rate of cows $(6.9 \%)$ with no udder pathogens was also demonstrated by Dudko (1990).

The cell counts in samples from quarters with different udder health status are given in Fig. 1 and Table 2. Fig. 1 graphically express the real arithmetic differences in SCC with respect to pathogen agents. As expected, bacterial infection markedly influenced the SCC in foremilk. The presence of both $S$. aureus and $S$. epidermidis increased the cell number by not more than 300 ' cells/ml compared to the uninfected quarter within the udder.

A stronger SCC, reaction was observed for micrococci and streptococci. However, when streptococci were divided into species it was found that $S$. agalactiae was about 500' SCC higher than streptococci except for S. agalactiae. Other authors (Vecht et al., 1989) have found generally similar responses with 
respect to bacterial infection. The cell count levels of different bacteria species probably reflects the virulence of the species (Hogan et al., 1988). Also the degree of virulence differs not only between but and within species of bacteria (Kostrzyński and Kozanecki, 1990).

The arithmetic means of SCC in foremilk (Table 2) correspond well with the data of Fig. 1. It permitted the use of SCC (as logarithm) for further statistical analysis which fully confirmed previous differences among types of bacterial infection. Finally, the overall arithmetic mean of cell count from infected quarters (958' per $\mathrm{ml}$ ) was much higher than that from non-infected quarters (313' cells). Major pathogens cause higher SCC (on average 1164' cells/ml) than minor pathogens $\left(579^{\circ}\right.$ cells $\left./ \mathrm{ml}\right)$. It should be pointed out in the present investigation that $S$. aureus, which is a species commonly classified as major pathogen, caused only a moderate elevation of the cell count. Therefore, in further analyses $S$. aureus and minor pathogens were combined into one class.

The standard deviations of the $\log \mathrm{SCC}$ were high and ranged between $11.5 \%$ (S. epidermidis) and 15.6\% (micrococci). They were somewhat lower than those reported by Dohoo et al. (1981), Lindstrom (1983) and Brolund (1985). Two-thirds of measurements in non-infected quarters were below $100^{\circ}$ and of $88 \%$ were below $500^{\prime}$ cells $/ \mathrm{ml}$. On the other hand, only single quarters with established micrococci infections showed cell counts with the same levels as for streptococci infections, many quarters $(29 \%)$ showed no cellular response at all (below $100^{\circ}$ cells). Consequently, a high proportion of infected samples with no or trace reaction in SCC reduced the differences between means of positive and negative quarters. This suggests that it is difficult to estimate reliable threshold values.

In the study reported here, the thresholds were determined twofold based on the normal distribution of LSCC.

First, the intersection points of the density distribution of the somatic cells in healthy and mastitis quarters were determined (Fig. 2). The basic experimental approach was to compare at least two quarters of the same udders, non-infected and infected, by specific bacteria. In the cows infected by streptococci the intersection points reached $179^{\circ}$ cells $/ \mathrm{ml}$, while in cows infected by other pathogens the critical cell count threshold was considerably lower ( $80^{\prime}$ cells $/ \mathrm{ml}$ ). A pooled cut off was obtained at SCC $=120^{\prime}$ cells $/ \mathrm{ml}$.

Next, considering that in a normally distributed population $98 \%$ of all samples are below a value corresponding to the mean plus 2 standard deviations, the value of $4.507 \pm 0.55$ for a LSCC of 134 healthy quarters (no pathogen and CMT reaction of 1 and 2) was used as estimates of upper limits for the healthy variation. The CMT is often used in investigations (e.g. by Dohoo et al.. 1981) as diagnosis parameter of udder health. A corresponding threshold $410^{\prime}$ cells $/ \mathrm{ml}$ 


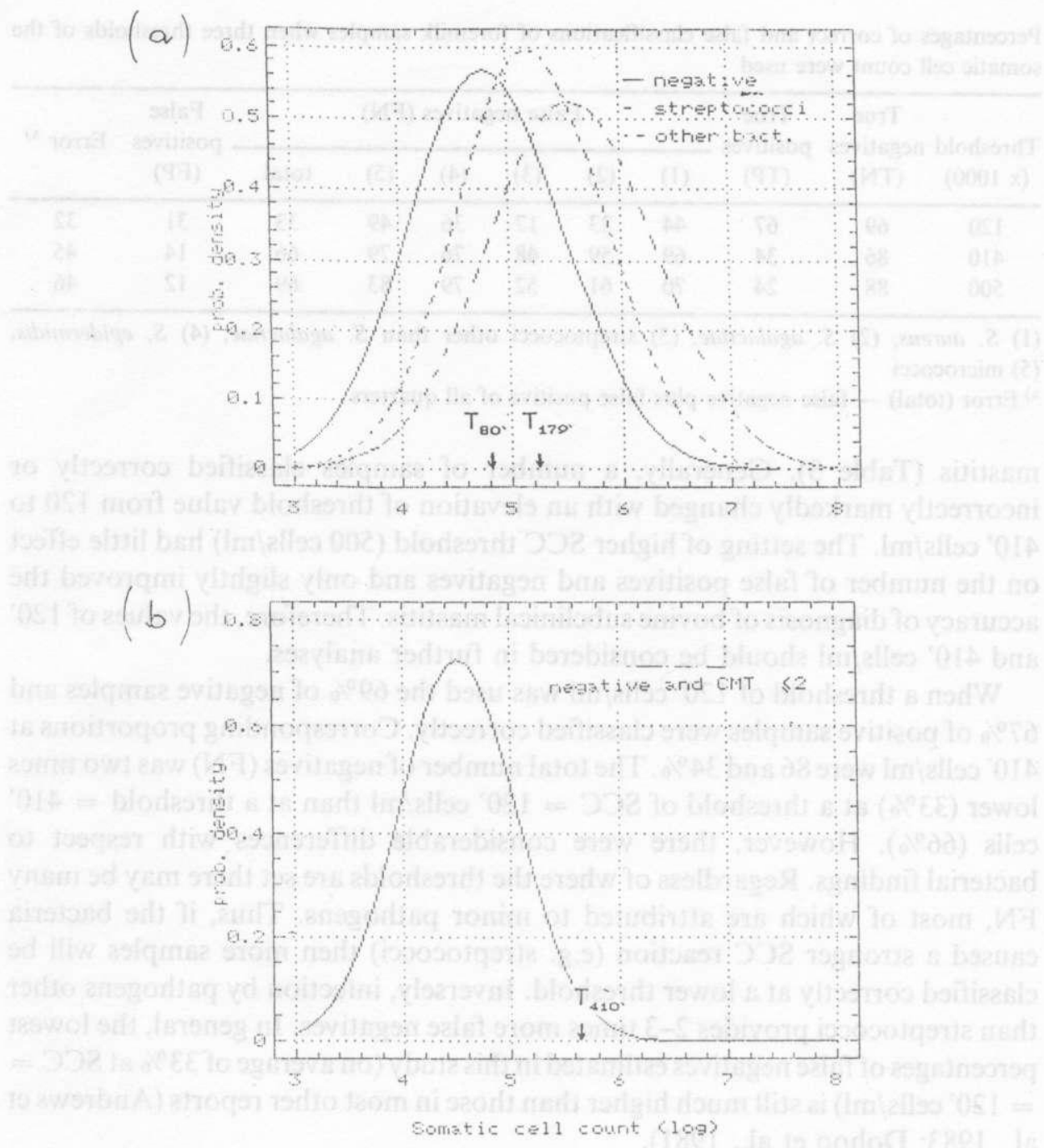

Fig. 2. Determination of threshold values $(t \times 1000)$ for the cell count in foremilk based on the frequency distribution: (a) - of groups unifected and infected by streptococci $\left(\mathrm{T}_{179}\right)$ and other bacteria $\left(\mathrm{T}_{80}\right)$; and $(\mathrm{b})$ - only of healthy quarters $\left(\mathrm{T}_{410}\right)$ (no pathogens and CMT score $\leqslant 2$ ).

was obtained which is also marked in Fig. 2. This value lies below standard cell count threshold of 500' cells per ml (IDF, 1987).

Two thresholds obtained from the present study, i.e. of $120^{\prime}$ and $410^{\prime}$ ' cells $/ \mathrm{ml}$ as a well as of 500' from IDF (1987) were examined as indicators of subclinical 
TABLE 3

Percentages of correct and false classifications of foremilk samples when three thresholds of the somatic cell count were used

\begin{tabular}{|c|c|c|c|c|c|c|c|c|c|c|}
\hline \multirow{2}{*}{$\begin{array}{l}\text { Threshold } \\
\text { (x 1000) }\end{array}$} & \multirow{2}{*}{$\begin{array}{c}\text { True } \\
\text { negatives } \\
\text { (TN) }\end{array}$} & \multirow{2}{*}{$\begin{array}{c}\text { True } \\
\text { positives } \\
(\mathrm{TP})\end{array}$} & \multicolumn{6}{|c|}{ False negatives (FN) } & \multirow{2}{*}{$\begin{array}{c}\text { False } \\
\text { positives } \\
\text { (FP) }\end{array}$} & \multirow{2}{*}{ Error ${ }^{x)}$} \\
\hline & & & (1) & (2) & (3) & (4) & (5) & total & & \\
\hline 120 & 69 & 67 & 44 & 23 & 17 & 36 & 49 & 33 & 31 & 32 \\
\hline 410 & 86 & 34 & 69 & 59 & 48 & 76 & 79 & 66 & 14 & 45 \\
\hline 500 & 88 & 24 & 70 & 61 & 52 & 79 & 83 & 69 & 12 & 46 \\
\hline
\end{tabular}

(1) S. aureus, (2) S. agalactiae, (3) streptococci other than $S$. agalactiae, (4) S. epidermidis, (5) micrococci

${ }^{x)}$ Error (total) - false negative plus false positive of all quarters

mastitis (Table 3). Generally, a number of samples classified correctly or incorrectly markedly changed with an elevation of threshold value from 120 to $410^{\prime}$ cells $/ \mathrm{ml}$. The setting of higher SCC threshold ( 500 cells $\left./ \mathrm{ml}\right)$ had little effect on the number of false positives and negatives and only slightly improved the accuracy of diagnosis of bovine subclinical mastitis. Therefore, the values of $120^{\prime}$ and $410^{\prime}$ cells $/ \mathrm{ml}$ should be considered in further analyses.

When a threshold of 120 ' cells $/ \mathrm{ml}$ was used the $69 \%$ of negative samples and $67 \%$ of positive samples were classified correctly. Corresponding proportions at 410 ' cells $/ \mathrm{ml}$ were 86 and $34 \%$. The total number of negatives (FN) was two times lower $(33 \%)$ at a threshold of SCC $=120^{\prime}$ cells $/ \mathrm{ml}$ than at a threshold $=410^{\prime}$ cells $(66 \%)$. However, there were considerable differences with respect to bacterial findings. Regardless of where the thresholds are set there may be many FN, most of which are attributed to minor pathogens. Thus, if the bacteria caused a stronger SCC reaction (e.g. streptococci) then more samples will be classified correctly at a lower threshold. Inversely, infection by pathogens other than streptococci provides 2-3 times more false negatives. In general, the lowest percentages of false negatives estimated in this study (on average of $33 \%$ at SCC $=$ $=120^{\prime}$ cells $/ \mathrm{ml}$ ) is still much higher than those in most other reports (Andrews et al., 1983; Dohoo et al., 1981).

It is quite possible that the high percentage of infected milk samples with no or weak SCC reaction could be caused by a streak of canal colonization or latent infections of the parenchyma (Heald et al., 1977). It is well known that most pathogens colonize the teat canal before they invade upper parts of the mammary glands (Schultze et al., 1978). According to Matilla (1985), subclinical infections by common pathogens often are accompanied by only a marginal increase in cell counts. The high prevalence also may indicate a high occurrence of short time infections which often are spontaneously eliminated (Timms and Schultz, 1984). 
The number of non-infected quarters classified as infected (FP) diminished from 31 to $14 \%$ as SCC in foremilk increased from 120 to $410^{\prime}$ cells $/ \mathrm{ml}$. Many biological (parity, stage of lactation, milk yield) and environmental herd (housing, feeding, milking procedures) factors can elevate the SCC in non-infected udders (Brolund, 1985). It is likely that higher lactation number (on average of 5-6) of cows and poor environment have been responsible for non-bacterial cells rising in the examined farms. Older cows have higher average cell counts than younger cows (Jaartsveld et al., 1983). In herds with extreme high/low milk yield the interpretation of the SCC in milk may also be difficult (Vecht et al., 1989).

The most important criterion in the selection of the somatic cell threshold is the intended use of the information. If the goal is to use the SCC information in mastitis control, the threshold must be set to express the true dynamics of mastitis, properly. It can say that in farms with high udder pathogen frequency, using $120^{\prime}$ cells $/ \mathrm{ml}$ as a threshold, will provide not more than $70 \%$ correct diagnosis. A large overlapping region between non-infected and infected samples prevents a reduction in misclassifications. A similar problem appeared in studies concerning the determination of the threshold value of SCC in large-scale farms. For instance, Sender et al. (1987) classified samples more correctly (with $82.6 \%$ at a threshold of $324^{\prime}$ cells $/ \mathrm{ml}$ ) than in present study, but also showed the large overlapping region of SCC. Thus, it could be presumed the high variability of SCC within the herd is a common problem, both in large and small herds.

On the other hand, if the SCC program is oriented toward treatment of udder infection, it would be appropriate to set the threshold low enough to assure that no infections are missed and thus go untreated. However, in practice one cannot expect that any reference diagnosis can give a true picture of udder health. According Andrews et al. (1983), when thresholds are chosen for dry cow therapy, much higher numbers of false positives instead of false negatives can be tolerated. Moreover, the choice of the threshold value is dependent on the milk loss/treatment expenses ratio. Some authors (Andrews et al., 1983) reported that yield of milk from subclinically affected udders may be reduced by up to $45 \%$, but no reliable Polish data are attainable for small farms. Using $410^{\prime}$ instead of $120^{\prime}$ cells $/ \mathrm{ml}$ results in a lower proportion of false positives $(14 \mathrm{vs} 31 \%$ ). The number of uninfected samples correctly diagnosed (around $90 \%$ ) is often used as the threshold SCC (Batra and McAllister, 1984). The $55 \%$ correct classifications achieved in the present study with a SCC threshold of $410^{\circ}$ cells $/ \mathrm{ml}$ is not promising for the near future, but it may be representative for many Polish regions. Since mastitis is a multifactorial disease, further studies, apart from bacteria, on the influence of different environmental and management factors on the SCC level in quarter as well in udder and bulk milk are needed. 
Monitoring of SCC in bulk milk, which has the place in most national programs, allows control of mastitis in a herd but it does not identify problem of cows. In commercial herds, an indirect method like the California Mastitis Test is often used in preliminary diagnosis of subclinical mastitis.

Comparison of Fossomatic and CMT data are shown in Table 4. The arithmetic average of somatic cells increased from 111 to $2136^{\prime}$ per ml with an increase in the CMT score from 1 to 5, respectively. The geometric means derived from $\mathrm{CMT}=1$ (negative) and $\mathrm{CMT}=2$ (trace) were similar, whereas the

TABLE 4

Agreement of CMT and distribution of pathogens in relation to CMT score

\begin{tabular}{ccccccccccccc}
\hline $\begin{array}{c}\text { CMT } \\
\text { score }\end{array}$ & $\begin{array}{c}\text { Mean of SCC } \\
(\times 1000)\end{array}$ & $\begin{array}{c}\text { Agreement } \\
\text { CMT }\end{array}$ & \multicolumn{4}{c}{$\begin{array}{c}\text { Distribution rate (\%) } \\
\text { of infection status }\end{array}$} & \multicolumn{2}{c}{$\begin{array}{c}\text { Percent of all } \\
\text { quarters }\end{array}$} \\
& A & G & $\%$ & $(0)$ & $(1)$ & $(2)$ & $(3)$ & $(4)$ & $(5)$ & infected uninfected \\
\hline I $(141)$ & 111 & 41 & A & 91 & 22 & 20 & 10 & 7 & 27 & 19 & 54 & 46 \\
$2(180)$ & 147 & 54 & A & 20 & 34 & 16 & 13 & 18 & 22 & 28 & 45 & 55 \\
$3(130)$ & 427 & 99 & B & 12 & 22 & 12 & 19 & 15 & 18 & 17 & 53 & 47 \\
$4(123)$ & 679 & 262 & $\mathrm{C}$ & 18 & 10 & 23 & 25 & 28 & 16 & 13 & 73 & 24 \\
$5(155)$ & 2136 & 827 & $\mathrm{D}$ & 10 & 12 & 29 & 33 & 32 & 17 & 23 & 77 & 23 \\
\hline$\leqslant 2(321)$ & 131 & 48 & $\mathrm{~A}$ & 94 & 56 & 26 & 23 & 25 & 49 & 47 & 49 & 51 \\
$\geqslant 3(414)$ & 1142 & $288^{\mathrm{B}}$ & 41 & 44 & 74 & 77 & 75 & 51 & 53 & 69 & 31 \\
\hline
\end{tabular}

(0) No pathogen. (1) S. aureus. (2) $S$. agalactiae. (3) streptococci other than $S$ agalactiae,

(4) S. epidermidis. (5) micrococci

$\mathrm{x} / \mathrm{CMT}_{1} \leqslant 200 ; \mathrm{CMT}_{2}=150-500 ; \mathrm{CMT}_{3}=400-1500 ; \mathrm{CMT}_{4}=800-5000 ; \mathrm{CMT}_{5} \geqslant 5000$

A, B, C. D - P $<0.01$

$\mathrm{A}$ - arithmetic, $\mathrm{G}$ - geometric mean

differences among other scores was significant $(P<0.01)$. No bacteriological status $x$ CMT score interaction, was detected. Comparison of CMT pattern with the arithmetic means for SCC obtained in present study demonstrate that lower values are assigned by Fossomatic than CMT. There is an agreement between CMT and Fossomatic scores, they decreased with increasing cell numbers to a low of $12 \%$ for $C M T=5$. However, if the test were grouped into two main classes (CMT $\leqslant 2$ as negatives and $\mathrm{CMT} \geqslant 3$ as positives) a percentage of agreement CMT was 94 and $41 \%$, respectively. In this study a phenotypic correlation of CMT score with somatic cell count was 0.61 . A higher correlation (0.74) was found by Batra and McAllister (1984). Thus CMT is a rough method to estimate the cell count. However, as is shown in Table 4, the larger streptococci infection $(75-77 \%)$ ) could be detected by a CMT score $\geqslant 3$ than infection by other bacteria $(51-74 \%)$. 
In the present work the CMT score $\geqslant 3$ as a threshold and the presence of microorganisms was used in a cause and effect model (IDF, 1987). Of 414 samples with a CMT score of $3-5$, only $69 \%$ were mastitic and the remainder of the samples were classified as nonspecific mastitis. On the other hand $49 \%$ of infected samples still had a CMT score $\leqslant 2$ (latent infection). Therefore, if individual measurements of $\mathrm{CMT}$ without laboratory diagnosis are used for selective antibiotic therapy, it must be accepted that appreciable numbers of infected cows will be treated and some infected cows will be not treated. From the present study it could be confirmed that the CMT test gives only an early indication of mastitis.

\section{REFERENCES}

Andrews R.J., Kitchen B.J.. Kwee W.S., Duncalfe F., 1983. Relationship between individual cow somatic cell counts and the mastitis infection status of the udder. Aust. J. Dairy Food Technol. 38. $71-74$

Batra T.R.. McAllister A.J., 1984. A comparison of mastitis detection methods in dairy cattle. Can J. Anim. Sci. 64, 305-312

Brolund L., 1985. Cell counts in bovine milk. Acta Vet. Scand. Suppl. 80, 1-123

Booth J.M., 1991. Mastitis cell count data. Mastitis Newsletter 16, $2-5$

Dohoo I.R.. Meek A.H., Martin S.W., Barnum D.A. 1981. Use of total and differential somatic cell counts from composite milk samples to detect mastitis in individual cows. Can. J. Comp. Med. $45,8-14$

Dudko P.. 1990. Różnice w ocenie stanu zdrowolnego wymion krów zależnie od metody badawczej. Prz. hod. 58, 15-17

Gordon W.A., Morris H.A., Packard V., 1980. Methods to detect abnormal milk - a review. J. Food Protect. 43, 58-65

Heald C.W., Jones G.M., Nickerson S.C., Patterson W.N., Vinson W.E., 1977. Preliminary evaluation of the Fossomatic somatic cell counter for analysis of individual cow samples in a central laboratory. J. Food Protect. 40, 523-526

Hogan J.S.. Smith K.L., Todhunter D.A., Shoenberger P.S., 1988. Rate of environmental mastitis in quarters infected with Corynehacterium bovis and Staphylococcus species. J. Dairy Sci. 71, $2520-2525$

Instrukcja. 1978. Rutynowe rozpoznanie drobnoustrojów patogennych dla gruczołu mlecznego krów. Min. Rolnictwa. Dep. Weterynarii, Warszawa, 1978

International Dairy Federation, 1987. Bovine mastitis. Definition and guidelines for diagnosis. IDF Doc. $211,1-24$

Jaartsveld F.H.J., Puffelen E., Oskam J., Tielen M.J.M., Verstegen M.W.A., Albers G.A.A., 1983. Somatic cell counts in milk of dairy cows in relation to stage of lactation, age. production level and presence of pathogens. Neth. Milk Dairy J. 37, 79-90

Kostrzyński St., Kozanecki M., 1990. Studies on the Staphylococcal etiology of mastitis in cows. Med. wet. 8, 275-277

Kozanecki M., Kostrzyński St., 1987. Studics on prophylaxy and control of udder diseases in cows in individual farms. Med. wet. 9, $552-554$

Kurck C., Milko K., Kacprzyński M., 1990. Microbiological assessment of milk raw 
material in the Gdansk region and the efficiency of the control of mastitis in the year $1983-1988$. Med. wet. 46, $398-400$

Lindstrom U.B., 1983. Effects of some herd factors and traits of the cow on bacterial scores and cell counts in quarter milk samples. Acta Agric. Scand. 33, 389-394

Malinowski F., Klossowska A., Krukowski H., Lesiak M.. Janiak K., 1992. State of health of udders and etiological agents causing mastitis in cow breeds in different regions of Poland. Med. wet. $48,216-218$

Mattila T., 1985. Diagnostic problems in bovine mastitis. Thesis. Helsinki, Finland, pp.1 - 100

Mijnen E., Jaartsved F.H.J., Albers G.A.A., Verstegen M.W.A., Tielen M.J.M., 1982. The value of cell count. lactose content, $\mathrm{pH}$ and conductivity of milk for mastitis detection in individual cows. Neth. Milk Dairy J. 36, 65-77

Sender G., Głąbówna M., Łukaszewicz. M., Bassalik-Chabielska L.. 1987. Environmental variability and threshold value of somatic cell count in milk. Milchwissenschaft 42,17-19

Schultze W.D.. Thompson P.D., Bright S.A., 1978. Inflammatory response of the bovine mammary gland to an irritant in the streak canal. Amer. J. Vet. Res. 39,785-790

Timms L.L., Schultz L.H., 1984. Mastitis therapy for cows with elevated somatic cell counts or clinical mastitis. J. Dairy Sci, 67, 367-37]

Wiśniowski J., Grajewski H., 1965. Comparative studies on the diagnostic value of "Mastirapid" used for the cell count in milk. Bull, vet. Inst. Putawy, 3, 84-87

Vecht U.. Wisselink H.J., Defize P.R.. 1989. Dutch national mastitis survey. The effect of herd and animal factors on somatic cell count. Neth. Milk Dairy J. 43, 423-435

\section{STRESZCZENIE}

\section{Liczba elementów komórkowych $w$ mleku $z$ chlopskich obór $z$ wysokim udziałem podklinicznych stanów zapalnych wymienia krów}

Badaniami objęto 213 krów z 77 gospodarstw chłopskich. Próbki mleka pobierano osobno z każdej ćwiartki wymienia. W mleku określono liczbę elementów komórkowych (SCC) przy pomocy aparatu Fossomatic i testu TOK oraz rodzaj zakażenia bakteryjnego. W $65,5 \%$ próbkach mleka stwierdzono obecność bakterii, spośród których najczęstszymi były $S$. agalactiae $(22,7 \%), S$. aureus $(18,8 \%)$ i $S$. epidermidis $(18,3 \%)$. Średni pomiar SCC, zależny od typu zakażenia, wahał się od 313 (mleko niezakażone) do $2128 \mathrm{tys} . \mathrm{ml}$ (mleko zakażone $S$. species), ale w znaczym procencie zakażonych próbek nie stwierdzono podwyższenia poziomu SCC. Wartość graniczna dla SCC obliczona dwoma sposobami wynosiła 120 lub 410 tys. $/ \mathrm{ml}$. Pozwalała ona na prawidłowe zidentyfikowanie odpowiednio w 68 lub 55\% próbek, ale jednocześnie 31 lub 14\% niezakażonych próbek zostało mylnie uznanych za zakażone. Test TOK wykrywał bakterie w mleku z $51--77 \%$ dokładnością. Korelacja między SCC a TOK wynosiła 0,61. Niezależnie od metody mierzenia poziomu elementów komórkowych, podkliniczny stan zapalny wymienia można było przewidzieć najdokładniej w przypadku obecności paciorkowców. 